\title{
Heat and Radiofrequency Plasma Glow Discharge Pretreatment of a Titanium Alloy: Eveidence for Enhanced Osteoinductive Properties
}

\author{
Bruce E. Rapuano ${ }^{1}$, Herman Singh ${ }^{1}$, Adele L. Boskey ${ }^{1}$, Stephen B. Doty ${ }^{1}$, and Daniel E. \\ MacDonald ${ }^{1,2,3,{ }^{*}}$ \\ ${ }^{1}$ Hospital for Special Surgery Affiliated With the Weill Medical College of Cornell University, New \\ York, New York, 10021 \\ ${ }^{2}$ General Medical Research, James J. Peters VA Medical Center, Bronx, New York, 10468 \\ ${ }^{3}$ Langmuir Center for Colloids and Interfaces, Columbia University, New York, New York, 10027
}

\section{Abstract}

It is believed that orthopedic and implant longevity can be improved by optimizing fixation, or direct bone-implant contact, through the stimulation of new bone formation around the implant. The purpose of this study was to determine whether heat $\left(600^{\circ} \mathrm{C}\right)$ or radiofrequency plasma glow discharge (RFGD) pretreatment of Ti6Al4V stimulated calcium-phosphate mineral formation in cultures of attached MC3T3 osteoprogenitor cells with or without a fibronectin coating. Calciumphosphate mineral was analyzed by flame atomic absorption spectrophotometry, scanning electron microscopy (SEM)/electron dispersive X-ray microanalysis (EDAX) and Fourier transformed infrared spectroscopy (FTIR). RFGD and heat pretreatments produced a general pattern of increased total soluble calcium levels, although the effect of heat pretreatment was greater than that of RFGD. SEM/EDAX showed the presence of calcium-and phosphorus-containing particles on untreated and treated disks that were more numerous on fibronectin-coated disks. These particles were observed earliest (1 week) on RFGD-pretreated surfaces. FTIR analyses showed that the heat pretreatment produced a general pattern of increased levels of apatite mineral at 2-4 weeks; a greater effect was observed for fibronectin-coated disks compared to uncoated disks. The observed findings suggest that heat pretreatment of Ti6Al4V increased the total mass of the mineral formed in MC3T3 osteoprogenitor cell cultures more than RFGD while the latter pretreatment hastened the early deposition of mineral. These findings help to support the hypothesis that the pretreatments enhance the osteoinductive properties of the alloy.

\section{Keywords}

dental implant; fibronectin; osteoblast; cell differentiation; bone mineralization; hydroxyapatite

While the outcomes of dental and orthopedic implant procedures are usually successful, in many instances the long-term stability and functionality of the implant is not achieved. Implant loosening and failure is still a significant problem with a sizeable percentage of hip arthroplasties. In fact, $25 \%$ of hip replacement surgeries reviewed in 2003 were revisions

(C) 2013 Wiley Periodicals, Inc.

"Correspondence to: Dr. Daniel E. MacDonald, Hospital for Special Surgery, 535 East 70th Street, New York, NY 10021. dem14@columbia.edu.

The authors declare that they have no conflict of interest. 
due to previous implant failure [Webster, 2003]. Despite the reported long-term predictability of dental implants [Adell et al., 1981, 1990], failures do occur in 10\% of cases within a 5-year period [Hardt et al., 2002]. The survival rates decrease to $71-83.5 \%$ over a 3.5-6 year period for dental implants placed in previously failed implant sites [Grossmann and Levin, 2007; Machtei et al., 2008]. The quality and quantity of bone that forms at the implant-skeletal interface is generally believed to be one of the major determinants for implant success [Johansson and Strid, 1994]. Therefore, improving fixation by enhancing the attachment and function of osteoblastic cells at the implant surface promises to substantially decrease the likelihood of failure, especially for implants placed in previously failed implant sites.

Due to their biocompatibility, commercially pure titanium (cpTi) and titanium alloys are widely employed in orthopedic and dental implants [Tengvall and Lundström, 1992; Larsson et al., 1996]. Titanium-Aluminum-Vanadium alloy is used in the fabrication of prosthetic joint replacements. This alloy, specifically in the form of Ti6Al4V, has even replaced cpTi in regions subject to high stress and dynamic loading such as hip prostheses and other articulating appendages because of the alloy's significantly greater mechanical strength [Ask et al., 1988; Lausmaa, 2001]. The Ti6Al4V alloy has also been successfully utilized in the dental field [Morris et al., 2001]. Both titanium and its alloys form an active oxide layer that readily interacts with extracellular matrix $(\mathrm{ECM})$ proteins produced by the cells and cell surface proteins. It is this superficial oxide found on both metals, $\mathrm{TiO}_{2}$ being the most abundant, that provides an interface that is biocompatible with peri-implant tissues [Kasemo, 1983; Imam and Fraker, 1996]. The surface oxide of Ti6Al4V is similar to that of pure titanium except that it is enriched with aluminum-oxide when present in air [Ask et al., 1988; MacDonald et al., 2004]. Altering the surface of titanium implant materials has been shown to affect protein adsorption, cell-substrate interactions, and tissue development [Sousa et al., 2008]. However. the mechanisms by which surface oxide properties modulate the bioactivities of bound osteogenic proteins and the function of bone-forming cells to influence osseointegration are poorly understood.

To prevent implant failure, a variety of methods have been explored, including the use of bioactive adhesive peptides or ECM proteins such as fibronectin to facilitate the attachment of osteogenic cells to the implant surface [Rezania et al., 1997; MacDonald et al., 1998, 2002; Sauberlich et al., 1999; Hynes, 2002; Barber et al., 2003; Sieving et al., 2003; Rapuano et al., 2004; Harbers and Healy, 2005]. Our laboratory and others have studied ECM proteins such as fibronectin or human bone sialoprotein (hBSP) or hBSP peptides following their non-covalent adsorption [MacDonald et al., 1998, 2002; Sauberlich et al., 1999; Sieving et al., 2003; Rapuano et al., 2004] or covalent grafting [Rezania et al., 1997; Hynes, 2002; Barber et al., 2003; Harbers and Healy, 2005] to the implant surface oxide to increase the adhesion of osteoblasts. Cell adhesion to fibronectin and other matrix proteins is primarily mediated by integrin receptors that recognize the tripeptide arginine- glycineaspartic acid (RGD) as an important protein binding site. Fibronectin is one of the most extensively studied components of the ECM with respect to its structure and cellular effects. The protein is an essential component for normal development, since fibronectin knockout mice fail to develop beyond embryonic day 10 or day 11 [George et al., 1993]. In studies where osteoprogenitor cell cultures were treated with anti-fibronectin antibodies (thereby reducing fibronectin stimulation of osteoblast integrin receptors), the expression of osteoblast gene markers and mineral nodule formation were significantly reduced in both early and late stages of development [Moursi et al., 1996]. Notably, since we have shown that fibronectin binds rapidly and irreversibly to TiO2 [MacDonald et al., 2002], the protein can be efficiently adsorbed to titanium materials without the use of intervening chemical coupling agents. However, the precise influence of the metal surface oxide on the capacity 
of fibronectin or other adsorbed osteogenic proteins to modulate osteoblast attachment and differentiation has yet to be fully elucidated.

An alternative approach to the use of fibronectin has employed porous titanium, scaffolds and microspheres as delivery systems for TGF-beta coatings to stimulate tissue regeneration and implant integration through the proliferation/differentiation of mesenchymal stem cells [Moioli and Mao, 2006; Moioli et al., 2006; Clark et al., 2008]. Although such strategies may increase bone formation at the interface they will not necessarily enhance bonding strength as effectively as approaches that promote osteoblast attachment and biomineralization directly on the surface of the implant. For this reason, interactions between the implant surface physico-chemical microenvironment and the bioactivities of osteogenic proteins while adsorbed to the surface will remain an important focus of investigation [Moioli and Mao, 2006; Moioli et al., 2006; Clark et al., 2008].

Many attempts have been made to improve bone formation around implants by influencing implant-specific factors. For example, implant surface characteristics, such as material surface topography, surface chemistry and implant geometries were altered in order to improve osseointegration [Joos et al., 2006]. Our earlier studies examined the effects of modifying surface oxide properties of Ti6Al4V, such as oxide chemistry or topography, on adsorbed fibronectin's bioactivity toward osteoblasts [MacDonald et al., 2004, 2011; Rapuano and MacDonald, 2011; Rapuano et al., 2012a]. These studies demonstrated that pretreating Ti6A14V surface oxide with heat or radiofrequency plasma glow discharge (RFGD) increased the oxide's negative net charge [MacDonald et al., 2011], dramatically increased the number of osteoblastic cells that attached to surface adsorbed fibronectin [Rapuano and MacDonald, 2011], and increased the exposure of fibronectin's integrin binding domain to enhance its binding to $\alpha_{5} \beta_{1}$ integrins in osteoblasts [Rapuano et al., 2012a]. These results suggested that heat or RFGD pretreatments of Ti6Al4V amplified fibronectin's intrinsic biological activity toward osteoblast integrins by inducing conformational changes in the matrix protein upon its adsorption. Later studies in our laboratory showed that fibronectin precoated on Ti6Al4V disks increased the peak expression of a panel of osteoblast gene markers [Rapuano et al., 2012b]. Heat and RFGD pretreatments were later found to increase the expression of all of the osteoblast gene markers analyzed in absence of a fibronectin coating, suggesting an effect of the pretreatments on the bioactivities of adsorbed osteogenic proteins [Rapuano et al., 2012c]. It was also observed that the pretreatments increased osteoblast gene expression for fibronectin-coated disks more than uncoated disks, suggesting a pretreatment-induced specific enhancement of fibronectin's bioactivity as well [Rapuano et al., 2012c].

In view of our previous findings [MacDonald et al., 2004, 2011; Rapuano and MacDonald, 2011; Rapuano et al., 2012a,b,c], the purpose of this study was to test the hypothesis that heat and RFGD pretreatments also stimulated mineral formation in vitro in cultures of attached MC3T3 osteoprogenitor cells and the sub-hypothesis that the effects of the pretreatments are amplified by the presence of a fibronectin coating. The hypothesis and sub-hypothesis were tested by using flame atomic absorption spectrophotometry to measure changes over time in total soluble calcium, SEM/EDAX to measure the atomic composition of the mineral formed by the osteoprogenitor cells and FTIR to measure changes in calciumphosphate mineral content, and the mineral: ECM ratio.

\section{MATERIALS AND METHODS}

\section{MATERIALS}

Fetal bovine serum (FBS) and cell culture media were from Invitrogen (Carlsbad, CA). Bovine serum albumin (BSA; Fraction V; essentially fatty acid-free) and human plasma 
fibronectin were purchased from Sigma-Aldrich (St. Louis, MO). All solutions for calcium analyses, including $\mathrm{HCl}$ and calcium standards were obtained from Fisher Scientific (Pittsburgh, PA). All other chemicals were from Sigma- Aldrich and were of spectroscopic grade. Tissue culture flasks $\left(75 \mathrm{~cm}^{2}\right)$ and 24-well tissue culture plates were obtained from Laboratory Disposable products (North Haledon, NJ).

\section{DISK PREPARATION}

Passivation and pretreatment of polished Ti6AI4V disks-Cylindrical implant disks (15mm diameter) were initially prepared from Ti6Al4V sheets obtained from TIMET (Wentzville, MO). Metal sheets were cut into strips, polished by machining and later punched into disks (Industrial Tool \& Die Co., Troy, NY) as previously described [MacDonald et al., 2011]. Disks were washed successively in isopropanol, acetone, xylene, acetone and $1 \mathrm{M}$ ammonium hydroxide, and rinsed with deionized water according to the ASTM-F86 protocol [F-86 AS, 1996]. The disks were then passivated in 40\% nitric acid and rinsed three times with deionized water. Disks were then dried and transferred into acidwashed scintillation vials in a HEPA filtered isolation hood (USA/Scientific, Ocala, FL) and stored closed in an auto-desiccator cabinet (Sanplatec Corp., Osaka, Japan). All disks were sterilized using a rapid dry heat oven (Alpha Medical, Hempstead, NY) for $5 \mathrm{~min}$. Some of the cleaned and passivated disks were further treated with RFGD or heat $\left(600^{\circ} \mathrm{C}\right)$. For heat pretreatment, disks were heated to a temperature of $600^{\circ} \mathrm{C}$ in air for $1 \mathrm{~h}$ [MacDonald et al., 2011]. RFGD plasma pretreatment of disks was performed using a modified Harrick RF unit (Ossining, NY; PDC-002) with a quartz chamber to subject samples to an oxygen plasma pretreatment [MacDonald et al., 2011]. Passivated Ti6Al4V disks were placed on a clean quartz tray. The tray was inserted into the RF unit and the unit was placed under dry vacuum (EcoDry-M oil-less vacuum pump; Leybold Vakuum, Köln, Germany). When the vacuum was low enough (1,600 mTorr) to remove all water vapor, oxygen was gradually bled into the system via a needle valve. The gas flow rate was monitored using an Omega shielded flow meter (Omega Technologies Co., Stamford, CT) at a rate of $250 \mathrm{ml} / \mathrm{min}$. All oxygen gas was prefiltered prior to its entry into the chamber (Advantec MFS, Inc., Pleasanton, CA). Samples of titanium alloy were treated with a $13.56 \mathrm{MHz}$ RF power-generated oxygen plasma for $5 \mathrm{~min}$ at 29.6W [MacDonald et al., 2011]. Following heat or RFGD pretreatment, disks were sterilized and stored as previously described for untreated specimens [MacDonald et al., 2004]. Treated discs were produced in the same manner as those analyzed previously for altered physicochemical properties [MacDonald et al., 2011] and continuous quality control was maintained for disk preparation/pretreatment. A regular analysis of disk topography and charge was performed to insure that treated disks employed in the current investigation possess the same physico-chemical properties as those analyzed previously [MacDonald et al., 2011].

\section{CELL CULTURE}

MC3T3-E1 cells (subclone 4; American Type Culture Collection; Manassas, VA) that exhibit high levels of osteoblast differentiation [Wang et al., 1999] were cultured in MEM-a with 10\% FBS (Invitrogen).

Cell culture conditions for measuring the effects of surface pretreatments on mineral formation-Ti6Al4V disks were placed into 24-well plates (Laboratory Disposable products) and incubated with $1 \times$ PBS or a $1 \mathrm{nM}$ fibronectin (Sigma-Aldrich)/1× PBS solution overnight at room temperature under a cell culture hood. At this concentration of fibronectin solution, a surface concentration of $120-170 \mathrm{ng}$ adsorbed fibronectin/ $/ \mathrm{cm}^{2}$ was obtained for untreated, heat-treated and RFGD-treated disks. No significant differences in fibronectin adsorption were found between the three groups [Rapuano and MacDonald, 2011]. We have shown that this coating concentration of fibronectin increased the 
attachment of MC3T3 cells to the titanium alloy six- to eightfold compared to uncoated disks [Rapuano and MacDonald, 2011] and increased the expression of osteoblast gene markers [Rapuano et al., 2012b]. The PBS and fibronectin/PBS solutions were removed and each disk was plated with 500,000 cells in MEM-a with 10\% FBS. A confluent cell monolayer was obtained 3 days following cell plating. Since this study focused on the effects of the alloy surface oxide and fibronectin coating on the function of differentiating, not proliferating osteoblasts, 3 days following the initial cell plating was designated as day 0 of the experimental period. On day 0 , the cultures began to be supplemented with $50 \mu \mathrm{g} / \mathrm{ml}$ ascorbic acid and $3 \mathrm{mM} \beta$-glycerophosphate. The cultures continued to receive fresh ascorbic acid and $\beta$-glycerophosphate with every media change during the remaining culture period until calcium was extracted, samples were fixed for SEM/EDAX analysis or mineral removed from disks for FTIR analyses at 1, 2, 3, or 4 weeks of the experimental period.

\section{CALCIUM ANALYSIS}

Cultures were rinsed twice in a calcium-free solution (saline; $0.9 \% \mathrm{w} / \mathrm{v}$ sodium chloride), lysed/scraped in $1 \mathrm{ml}$ of $1 \mathrm{~N} \mathrm{HCl}$, and incubated (for acid hydrolysis) at $110^{\circ} \mathrm{C}$ overnight. Acid hydrolyzates were routinely stored at $4^{\circ} \mathrm{C}$. Calcium concentrations were measured using flame atomic absorption spectroscopy [Willis, 1960]. Changes in the concentrations of total soluble calcium were measured at 1,2,3, or 4 weeks following the start of ascorbic acid/ $\beta$-glycerophosphate supplementation. Control samples received no fibronectin precoating. For each experimental condition (untreated, heat-treated or RFGD-treated), experiments measuring calcium were repeated at least three times at all of the time points (each experiment was performed with a separate independent cell culture). Data for each independent culture was averaged from the assay of cultures from four replicate disks at each time point.

\section{SEM/EDAX ANALYSES OF MINERAL COMPOSITION}

After 1-4 weeks of culture in media supplemented with ascorbic acid and $\beta$ glycerophosphate, supernatants were aspirated, the titanium alloy disks were washed $1 \times$ with (1 ml) 4\% paraformaldehyde and incubated in a second aliquot of this fixative for 2-3 h. Disks were then washed $3 \times$ with $(1 \mathrm{ml})$ distilled water and air-dried. The disks were sputter-coated with a thin layer of palladium and analyzed by high vacuum scanning electron microscopy (FEI, Quanta 600, Peabody, MA) in the secondary electron mode. All specimens were imaged at a magnification of 2,000-5,000× and a voltage of $20 \mathrm{kV}$. Electron dispersive X-ray microanalysis (EDAX) of calcium, phosphorus, titanium, aluminum, and vanadium was performed (EDAX-DX4, EDAX International, Mahwah, NJ.). Spectra were collected at a magnification of 2,000-5,000×, using $20 \mathrm{kV}$ voltage, and a collection time of $1 \mathrm{~min}$. The count rate was set for 1,000 counts per second for the scans which were routinely corrected for baseline prior to EDAX analysis [MacDonald et al., 2000]. Calcium: phosphorus mass ratios were determined by dividing the area under the curve (AUC) for the calcium elemental scan by the AUC for the phosphorus elemental scan. For each experimental condition (untreated, heat-treated or RFGD-treated), experiments measuring calcium and phosphorus were repeated at least three times at all of the time points (each experiment was performed with a separate independent cell culture). Within each experimental group, data for each independent culture was averaged from the analyses of particles selected from two regions of the same disk at each time point for uncoated and fibronectin-coated disks.

\section{FTIR ANALYSES OF MINERAL AND MATRIX PROPERTIES}

For FTIR studies, culture media was aspirated and disks were allowed to air dry overnight. Freshly dried $\left(120^{\circ} \mathrm{C}, 24 \mathrm{~h}\right) \mathrm{KBr}(200 \mathrm{mg})$ was mixed with the air-dried samples on the disks and pellets were made for spectroscopic analysis. Each sample corresponded to 0.5- 
$1 \%$ of the weight of the $200 \mathrm{mg} \mathrm{KBr}$ used to prepare the pellets. Spectra were obtained with an IR spectrometer (Nicolet 6700 FTIR Spectrometer, Thermo Fisher Scientific, Waltham MA). After acquisition, spectra were truncated to allow analysis of the regions of interest and then zero-corrected for baseline. All spectral data processing was performed using a commercial software package (Grams 32 software, Galactic Industries, Salem, NH.). The levels of calcium-phosphate mineral were measured as the area under the apatite phosphate peak (900-1,180 $\mathrm{cm}^{-1}$ ) after subtracting control (no supplementation with ascorbic acid or $\beta$-glycerophosphate) values. The mineral to matrix ratio was measured as the area under the phosphate peak $\left(900-1,200 \mathrm{~cm}^{-1}\right)$ divided by the area under the amide I peak $(1,585-1,720$ $\mathrm{cm}^{-1}$ ) after subtracting control (no supplementation with ascorbic acid or $\beta$ -

glycerophosphate) values for the mineral to matrix ratio. For each experimental condition (untreated, heat-treated, or RFGD-treated), experiments were repeated at least three times at each time point (each experiment was performed with a separate independent cell culture).

Samples from four replicate disks were pooled to obtain one spectrum for each independent culture analyzed at each time point.

\section{STATISTICAL ANALYSIS}

Data are presented as mean \pm standard error of the mean ( $\mathrm{N}=$ total number of independent cell cultures). Data were normally distributed. The variability of data was similar for all experimental conditions at each time point and similar for all time points for each experimental condition. Statistical comparisons were performed using an ANOVA with the alpha level set at 0.05 . For any significant differences shown, the $\mathrm{p}$ value for the ANOVA was $0.05-0.001$. Only the results of the post tests for multiple comparisons are shown in the figure legends.

\section{RESULTS \\ EFFECTS OF HEAT AND RFGD PRETREATMENTS OF TI6AI4V ON TOTAL SOLUBLE CALCIUM IN MC3T3 OSTEOPROGENITOR CELL CULTURES}

Measurements of total soluble calcium by atomic absorption spectrophotometry showed progressive and statistically significant increases in calcium levels over time in cultures of osteoprogenitor cells attached to untreated, heat-pretreated or RFGD-pretreated disks (Fig. 1). Both heat and RFGD pretreatments increased total soluble calcium levels by $20-30 \%$ and $30-50 \%$ in the first and second week of culture, respectively, for fibronectin-coated and uncoated disks compared to untreated disks. However, only the heat pretreatment produced statistically significant increases in total soluble calcium compared to untreated disks for fibronectin-coated or uncoated disks after 1-2 weeks of culture (Fig. 1). By 3 weeks, only the heat pretreatment appeared to have increased calcium levels for both coated and uncoated disks compared to the 3 week untreated disk group. By week 4 , the differences between the three study groups in total soluble calcium levels had largely disappeared (Fig. 1).

\section{ELECTRON MICROSCOPIC AND EDAX ANALYSES OF MINERAL FORMED IN MC3T3 CELL CULTURES}

Figure 2 shows representative scanning electron microscopic images of untreated and treated disks after 4 weeks of cell culture in media supplemented with ascorbic acid and $\beta$ glycerophosphate with or without fibronectin. All of the images show what appears to be a network of fibers presumably due to the deposition of ECM proteins. The images also show particles that mostly varied in diameter from 100 to $1,000 \mathrm{~nm}$ and appeared brighter than the background (Fig. 2). These particles were found overlying or in between the fibers for untreated, heat-pretreated and RFGD-pretreated disks. In general, the average diameter and 
number of these particles increased at each successive timepoint and more of these particles were found on fibronectin-coated disks compared to uncoated disks (unpublished results).

To verify that these particles represented hydroxyapatite, their atomic composition was analyzed by electron dispersive EDAX. EDAX analysis showed that the particles analyzed contain both calcium and phosphorus in variable amounts. EDAX was also used to measure the calcium to phosphorus mass ratio for individual particles. This ratio was determined by dividing the AUC for the calcium peak by the AUC for the phosphorus peak after correcting for baseline. Calcium:phosphorus mass ratios obtained for representative individual particles found on uncoated and fibronectin-coated disks (after 3 weeks of cell culture) are shown in Figure 2. Notably, no particles of any size containing calcium or phosphorus were detected on untreated or heat-pretreated disks until the 2 week time point (Fig. 3). In contrast, calcium and phosphorus-containing particles with a Ca:P mass ratio close to 0.5 were found on RFGD-pretreated disks that were uncoated or coated with fibronectin as early as week 1 (Fig. 3). A sharp increase in the Ca:P mass ratio from approximately 0.5 to 1.0 was observed in all three experimental groups between weeks 2 and 3. Statistically significant increases were found for several experimental conditions in the Ca:P mass ratio measured at 3 and 4 weeks compared to weeks 1 and 2 (Fig. 3). Very little change in this ratio was observed for most experimental conditions between weeks 3 and 4 with mean values for the Ca:P mass ratio ranging from 1.0 to nearly 1.3 (Fig. 3). Synthetic HA prepared in our laboratory and analyzed by EDAX demonstrated a Ca:P mass ratio of 1.25 .

For some osteoprogenitor cultures, there was a thick calcium-containing layer of material covering the metal characterized by large calcium and phosphorus peaks and a very small titanium peak in the EDAX spectra (Fig. 4). The spectra also reveal the presence of organic elements on or near the surface of the particles and the other underlying metallic elements of the alloy, namely aluminum and vanadium. Increases in the thickness of the calciumcontaining or other organic material on the surface cause the metal peaks to become smaller due to shielding from exposure to the X-ray beam. Figure 4 shows images from three different areas of the same RFGD-pretreated disk that contained a thick layer of mineral following 4 weeks of incubation with $50 \mu \mathrm{g} / \mathrm{ml}$ ascorbic acid and $3 \mathrm{mM} \beta$-glycerophosphate. EDAX analysis of a representative particle in each region yielded calcium:phosphorus mass ratios between 1.3 and 1.4 (Fig. 4).

\section{FTIR SPECTROSCOPIC ANALYSES OF MINERAL FORMED IN MC3T3 CELL CULTURES}

FTIR spectroscopic analyses of 4 week cultures were performed to determine whether there were differences between the study groups in mineral content and the mineral to matrix ratio. Figure 5 shows representative FTIR spectra for cultures grown on uncoated or fibronectin-coated disks pretreated with RFGD or heat compared to that obtained for synthetic hydroxyapatite. The spectrum obtained for synthetic hydroxyapatite exhibited the characteristic apatite phosphate peak at $900-1,200 \mathrm{~cm}^{-1}$ (Fig. 5). All of the spectra obtained for both uncoated and fibronectin-coated RFGD (Fig. 5A) or heat pretreated (Fig. 5B) Ti6Al4V disks showed the characteristic matrix protein amide I (including collagen) and amide II peaks as well as a peak resembling that of apatite phosphate.

FTIR spectroscopic analyses revealed that both the levels of calcium-phosphate mineral and the mineral:matrix ratio appeared to progressively increase with time over the 4-week period of incubation with ascorbic acid and $\beta$-glycerophosphate (Fig. 6). Statistically significant two- to fourfold increases in the extent of mineralization were found at 4 weeks compared to weeks 1 and 2 for heat and RFGD-pretreated disks (Fig. 6A). FTIR spectroscopy showed that fibronectin coated-disks generally exhibited higher levels of calcium-phosphate mineral after 2-4 weeks of culture compared to uncoated disks. Also, the heat pretreatment of disks generally increased the levels of calcium-phosphate mineral after $2-4$ weeks of culture 
(compared to untreated disks) to a greater degree for fibronectin-coated disks than for uncoated disks. For RFGD-pretreated disks, statistically significant increases in the mineral:matrix ratio were found at 3 and 4 weeks compared to earlier time points (Fig. 6B). Also, the RFGD pretreatment produced a pattern of increases in the mineral:matrix ratio at all of the time points analyzed compared to untreated disks (Fig. 6B).

\section{DISCUSSION}

\section{STIMULATION OF MINERAL FORMATION IN MC3T3 OSTEOPROGENITOR CELL CULTURES BY HEAT AND RFGD PRETREATMENTS OF TI6AI4V}

A major finding in the current study is that both pretreatments of uncoated or fibronectincoated Ti6Al4V promoted increases in total soluble calcium in MC3T3 cell cultures during the first 2 weeks of incubation with osteogenic media. All cultures were washed twice with a calcium-free solution before the addition of $1 \mathrm{~N} \mathrm{HCl}$ to extract mineral and the $1 \mathrm{ml}$ of media in each culture only contained approximately $2 \mu$ moles or $0.08 \mathrm{mg}$ calcium. Therefore, the calcium measured $(0.2-0.5 \mathrm{mg})$ per disk is likely to be almost entirely what was released from precipitated mineral by acid hydrolysis. These results suggest that RFGD and heat pretreatments increased calcium-phosphate mineral formation in MC3T3 cell cultures irrespectively of whether the alloy disks were coated with fibronectin or left uncoated, although the effects of the latter pretreatment appeared to be greater. In parallel with these results, we have reported that heat and RFGD pretreatments of Ti6Al4V materials increased the expression of osteoblast gene markers (including osteopontin, bone sialoprotein and osteocalcin) in the first 2 weeks of culture for both fibronectin-coated disks and uncoated disks [Rapuano et al., 2012c]. These findings suggest that both pretreatments enhance the osteoinductive properties of the titanium alloy. Furthermore, we have also shown that heat pretreatment increased both calcium-phosphate mineral levels determined by FTIR spectroscopy (reported in the current study) and osteoblast/matrix gene expression [Rapuano and MacDonald, 2011] at 2-4 weeks (compared to untreated disks) to a greater degree for fibronectin-coated disks than for uncoated disks. These latter findings collectively suggest that heat pretreatment amplified fibronectin's stimulatory effects on osteoblast differentiation, ECM synthesis and calcium-phosphate mineral formation in MC3T3 cell cultures by increasing the adsorbed protein's intrinsic bioactivity.

The results of the current study have shown that both the levels of calcium and the $\mathrm{Ca}: \mathrm{P}$ ratio increased progressively over time in parallel with each other and with the progressive time-dependent dramatic increases in osteoblast marker gene expression that that we have previously reported [Rapuano et al., 2012b]. The results also show that our pretreatments promoted significant increases in the calcium deposited over the same time scale for which they have been shown to increase osteoblast marker gene expression as we have previously reported [Rapuano et al., 2012c]. These findings suggest that measuring the total soluble calcium deposited provides an index of the extent of mineralization on the surface of the titanium alloy disks studied. Of course these measurements do not provide information concerning the spatial distribution of any mineral on the surface. However, it is likely that increases in the levels of total calcium deposited reflect increases in the $\%$ surface coverage by mineral, which is highly relevant to implant integration in vivo.

\section{CELL-MEDIATED VERSUS DYSTROPHIC MINERALIZATION IN MC3T3 OSTEOPROGENITOR CELL CULTURES}

We have previously reported that the osteogenic cells used in the current study displayed a number of characteristics when attached to Ti6Al4V, such as increases in the expression of type I collagen and osteocalcin [Rapuano et al., 2012b], that are exhibited by the cell types that demonstrated a capability for biomineralization in the study by Declercq et al. [2005]. 
In the current study, we used subclone 4 of the MC3T3-E1 cell line that displays high levels of osteoblast differentiation [Wang et al., 1999], suggesting that it is enriched in osteoprogenitors compared to the parental cell line. Following their attachment to untreated Ti6Al4V without a fibronectin coating, we have previously shown that these subclone 4 cells demonstrated 25- to 30-fold and five- to 15-fold increases in type I collagen and osteocalcin mRNA levels, respectively, after 2-4 weeks of culture [Rapuano et al., 2012b]. The transcript levels for type I collagen, osteocalcin and several other osteoblast and ECM gene markers were further amplified both by a fibronectin coating [Rapuano et al., 2012b] and by our surface pretreatments [Rapuano et al., 2012c]. These data illustrate that subclone 4 cells manifest a capacity for osteoblast differentiation when cultured on the titanium alloy that may also be augmented by biomimetic surface coatings or changes in the oxide.

In the current study, SEM showed what appeared to be a network of fibers presumably due to the deposition of ECM proteins. Type I collagen is likely to be a component of this network of fibers in view of the dramatic increases over time that we have observed in the expression of the type I collagen gene in MC3T3 cell cultures on both untreated [Rapuano et al., 2012b] and pretreated [Rapuano et al., 2012c] alloy disks. On pretreated and untreated disks alike, these fibers appeared to be associated with numerous particles containing calcium and phosphorus as determined by SEM/EDAX, many of which had calcium:phosphorus mass ratios approaching that of synthetic hydroxyapatite measured by EDAX. Finally, when disks were coated with fibronectin, a matrix protein that we have shown increases osteoblast gene marker expression [Rapuano et al., 2012b], more calciumphosphorus particles associated with the fibers were observed in SEM images and generally more mineral was measured by FTIR compared to uncoated disks. These and other findings described above suggest that MC3T3-subclone 4 cells attached to Ti6A14V possess a capacity for forming and actively mineralizing an ECM. The overall findings in the current study together with our previous studies [Rapuano et al., 2012b,c] also suggest that this capacity for biomineralization is enhanced by the stimulatory effects of fibronectin [Rapuano et al., 2012b] and surface pretreatments [Rapuano et al., 2012c] on osteoblast differentiation.

The capability of MC3T3-subclone 4 cells cultured on Ti6Al4V for forming a mineralized matrix can be further evaluated by comparing our results with those of other studies that examined the osteogenic potential of MC3T3 cells. Bonewald et al. [2003] reported that only rare or sparse dystrophic mineralization of unknown chemical origin and not associated with collagen was evident in MC3T3-E1 cells grown on tissue culture plastic. In contrast, the mineral formed in 16- day fetal rat calvarial cell cultures in the presence of $100 \mu \mathrm{g} / \mathrm{ml}$ ascorbic acid and $2.5 \mathrm{mM} \beta$-glycerophosphate consisted of a bonelike apatite that was generally associated with collagen fibers, and exhibited a mineral:matrix ratio of 0.56 [Bonewald et al., 2003]. In our study, the mineral-to-matrix ratio in MC3T3-subclone 4 cells determined by FTIR ranged as high as 0.55 (corrected for control nonmineralizing cultures) after 28 days of culture in the presence of $50 \mu \mathrm{g} / \mathrm{ml}$ ascorbic acid $/ 3 \mathrm{mM} \beta$-glycerophosphate. Notably, the ratio measured for (high differentiating capacity) subclone 4 cells at 28 days in our study was three times higher for untreated disks and five times higher for pretreated disks compared to that measured for the non-mineralizing parental MC3T3-E1 cell line in the study by Bonewald et al. [2003] at comparable concentrations of $\beta$ glycerophosphate ( $3 \mathrm{mM}$ vs. $2.5 \mathrm{mM}$, respectively). It is not surprising that other investigators have found evidence of cell-mediated calcification in cultures of the MC3T3-E1 parental line [Sudo et al., 1983; Franceschi and Iyer, 1992], since it is likely that its properties sometimes change due to variations in culture conditions, serum, and clonal selection. Most importantly, these findings lend further support to the hypothesis that subclone 4 cells can form and mineralize an ECM when cultured on Ti6Al4V. 
Measurements of the calcium:phosphorus mass ratio were also used to evaluate the capacity of the MC3T3 cells for biomineralization on Ti6A14V materials. Of course absolute measurements of the Ca:P mass ratio by EDAX are a function of the system's efficiency of detecting the emitted X-rays which can be affected by their energy/direction and the thickness, density, and topography of the material they must pass through to reach the detector. However, the tightness of the EDAX data obtained from different regions of the same disk (Fig. 4) indicate that EDAX could be used for relative measurements if not for absolute analyses of mineral composition. In the current study, particles analyzed at 4 weeks of cell culture were found to have a mean $\mathrm{Ca}: \mathrm{P}$ ratio as high as 1.25 , which was equivalent to that of synthetic HA as measured by EDAX in our laboratory. It has been reported by Meng et al. [2009] that mineralizing MC3T3 cells cultured on silicon substrates contain particles that exhibit Ca:P mass ratios measured by EDAX between 0.55 ( 2 weeks of culture) and 1.2 (4 weeks). In the latter study, the presence of hydroxyapatite was confirmed by synchrotron grazing incidence X-ray diffraction [Meng et al., 2009]. The range of sizes of these particles and their Ca:P mass ratios [Meng et al., 2009] were very similar to those found in the current study for the same respective culture times. These findings provide additional evidence that MC3T3 cells attached to a Ti6A14V substrate are capable of biomineralization.

\section{THE COMPARATIVE EFFECTS OF RFGD AND HEAT PRETREATMENTS ON MINERALIZATION IN MC3T3 OSTEOPROGENITOR CELL CULTURES}

Both heat and RFGD pretreatments of Ti6Al4V produced a pattern of early (1-2 weeks) increases in total calcium in MC3T3 cell cultures that suggested a stimulation in mineralization by both pretreatments. EDAX findings that calcium and phosphoruscontaining particles form earlier on RFGD-pretreated surfaces compared to untreated or heat-pretreated surfaces also suggested that this particular pretreatment may hasten the formation of initiation sites for HA crystals. RFGD pretreatment may have accelerated the formation of HA initiation sites to a higher degree than heat pretreatment due to its greater induction of bone sialoprotein [Rapuano et al., 2012c], which is known to promote HA nucleation [Hunter and Goldberg, 1993]. This latter effect might also account for the slightly higher mineral: matrix ratios observed for RFGD-pretreated disks compared to the untreated alloy assuming that bone sialoprotein is more efficient in promoting HA nucleation than other ECM proteins. Therefore, our findings suggest that RFGD pretreatment increases the amount of mineral per unit of matrix protein possibly through effects on HA formation.

For the preheated alloy, the total calcium levels per (fibronectin-coated or uncoated) disk observed from 1 to 3 weeks of culture and the total levels of mineral per (fibronectin-coated) disks (measured by FTIR) at 2-4 weeks appeared to exceed those measured for either untreated or RFGD-pretreated disks. These latter findings suggest that heat pretreatment increased the amount of mineral per disk to a greater extent than RFGD pretreatment and are consistent with the former pretreatment's greater induction of osteocalcin [Rapuano et al., 2012c], since it is a key marker of osteoblastic cells that are capable of biomineralization [Declercq et al., 2005]. Measurements of osteocalcin gene expression suggest that more osteoprogenitors differentiated on preheated disks compared to the RFGD-pretreated alloy [Rapuano et al., 2012c]. Therefore, differences between RFGD and heat pretreatment in their effects on mineral formation may have arisen from their respective effects on MC3T3 cell expression of a specific matrix protein that modulates HA nucleation and the proportion of these cells that differentiate into osteoblasts [Rapuano et al., 2012c].

Findings in the current study that preheating increased mineral levels without significantly increasing the mineral:matrix ratio compared to untreated disks indicate that preheating also raised the levels of matrix synthesis. This latter putative effect would replicate our earlier finding that a key direct osteogenic effect of heat pretreatment is on osteoblast 
differentiation/matrix protein expression, potentially leading to increases in the mass of both mineral and matrix but not necessarily in the amount of mineral that forms per unit of matrix protein [Rapuano et al., 2012c]. The effects of heat pretreatment on the total levels of mineral formed per disk is highly relevant to the clinical outcome we are most interested in predicting which is the amount of bone that will form in the defect created by the insertion of our modified implant materials. Our results showing that preheating the alloy increases total soluble calcium and HA levels are also consistent with our recent findings that preheated Ti6Al4V implants placed into rat femurs have a higher implant-bone shear strength than untreated implants (unpublished results). Notably, the peak mineral:matrix ratio measured for MC3T3 cells cultured on preheated surfaces (nearly 0.5) in the current study was comparable to that of mineralizing cell cultures as discussed above [Declercq et al., 2005]. Also, numerous particles with Ca:P mass ratios similar to HA were observed overlying an organic (cells and matrix) layer covering the preheated disks. Therefore, the stimulation of mineral formation by heat pretreatment is more likely to represent an organized cell-mediated process than a direct non-cellular effect on HA crystal formation due to altered surface oxide properties that we have previously reported [MacDonald et al., 2004, 2011].

\section{EFFECTS OF TI6AI4V OXIDE STRUCTURAL AND CHEMICAL PROPERTIES ON THE FORMATION OF A MINERALIZED MATRIX IN MC3T3 CELL CULTURES}

The differences between the two pretreatments of Ti6Al4V in their coordinate effects on osteoblast marker gene expression and biomineralization in MC3T3 cell cultures may have arisen from the unique physicochemical characteristics of each resultant oxide surface. Although both heat and RFGD pretreatments alter the Ti6Al4V oxide's net surface charge [with the latter pretreatment exerting a greater effect; MacDonald et al., 2011], only heat pretreatment also altered oxide elemental composition and topography by creating a pattern of oxide elevations that were approximately $50-100 \mathrm{~nm}$ in diameter [MacDonald et al., 2011]. In contrast, the RFGD pretreatment of Ti6Al4V disks did not alter the atomic composition or topography of the alloy surface [MacDonald et al., 2011]. The differences between the two pretreatments in their effects on the Ti6Al4V oxide were paralleled by differences in their effects on osteoblast and matrix gene marker expression [Rapuano et al., 2012c]. Other studies have shown that treatments of titanium implant materials that increase surface roughness, hydrophilicity or roughness and hydrophilicity concomitantly can all have different and unpredictable effects on osteoblast gene expression [Zhao et al., 2007; Olivares-Navarrete et al., 2010; Klein et al., 2011], inducing some osteoblast gene markers while repressing others [Zhao et al., 2007]. These findings suggest that changes in surface oxide chemistry and topography interact in a complex manner to cooperatively modulate the expression of specific osteoblast and matrix gene markers, potentially resulting in quantitative and qualitative changes in biomineralization.

Variations in the expression of some osteoblast matrix genes that are induced by our pretreatments, such as those for type I collagen ( $\alpha 1$ ), osteopontin, and bone sialoprotein [Rapuano et al., 2012c], alter the protein composition of the matrix and the biochemical cues it provides for osteoblast differentiation and cell-directed mineralization. Even without cells or a matrix, calcium salts can precipitate on titanium oxides incubated in the cell culture media used in the current study [ter Brugge et al., 2002]. However, these calcium deposits are short-lived and almost completely disappear within 24 days, measuring $<5 \mu \mathrm{g}$ for $15 \mathrm{~mm}$ diameter disks [ter Brugge et al., 2002] compared to levels $>60 \mu \mathrm{g}$ measured in the current study in 28-day MC3T3 cell cultures (also using $15 \mathrm{~mm}$ diameter disks). Therefore, it is the changes in the composition of the matrix, not the oxide per se, that are most likely to be directly linked to the effects of our pretreatments on mineral formation as demonstrated in the current study. It is also possible that heat and RFGD-modified oxides directly modulate 
the conformational bioactivities of matrix proteins deposited on the alloy by MC3T3 cells as we have previously demonstrated for adsorbed fibronectin [Rapuano et al., 2012a]. Finally, we have shown that the pretreatments of TiAl4V enhance matrix gene/osteoblast marker gene expression [Rapuano et al., 2012c] and promote biomineralization (as reported in the current study) even in the absence of an exogenous fibronectin coating. These latter results suggest that the bioactivities of other osteogenic proteins present in MC3T3 cell cultures are also increased upon adsorption to the modified Ti6Al4V surface oxide. Therefore, the distinct effects of Ti6Al4V oxide chemistry, roughness and topography on the surface bioactivities of fibronectin and other osteogenic proteins, matrix protein composition/ bioactivity and osteoblast differentiation may all contribute to the differences observed between RFGD and heat pretreatments in their effects on mineral formation.

\section{CONCLUSIONS}

Heat and RFGD pretreatments of fibronectin-coated and uncoated Ti6Al4V promoted increases in calcium:phosphate mineral formation by MC3T3 osteoprogenitor cells through an enhancement of fibronectin's bioactivity and possibly other mechanisms that may involve the modulation of multiple osteogenic and matrix proteins. Heat pretreatment of the alloy increased the levels of hydroxyapatite for fibronectin-coated disks and total soluble calcium to a greater degree than RFGD pretreatment. This is perhaps related to the former pretreatment's previously demonstrated greater induction of osteocalcin, which suggested that more MC3T3 osteoprogenitors differentiate into osteoblasts on the preheated Ti6Al4V surface. In contrast, SEM/EDAX analysis of calcium and phosphorus containing particles indicated that RFGD pretreatment may have accelerated the formation of initiation sites for HA crystals compared to the other treatment groups. This effect of RFGD may have been due to its previously reported greater induction of bone sialoprotein, which is known to promote $\mathrm{Ca}-\mathrm{PO}_{4}$ nucleation. These findings help to support the hypothesis that pretreatments of Ti6Al4V that modify its surface oxide enhance the osteoinductive properties of the alloy.

\section{Acknowledgments}

The project described was supported by Grant Number NIH RO1 DE017695 (Awarded to DEM). The sponsor did not have any role in the study design; the collection, analysis and interpretation of data; the writing of the report; or the decision to submit the article for publication. This material is also the result of work supported with resources and the use of facilities at the James J. Peters VA Medical Center, Bronx, New York. This investigation was also conducted at the HSS research facility constructed with support of Grant C06- RR12538-01 from the National Center for Research Resources, NIH. We would like to acknowledge Tony Labissiere for technical assistance with the SEM/EDAX analyses. We would also like to acknowledge Hayat Taleb, Kyle Hackshaw, and Carrie Guan for assistance with FTIR and atomic absorption spectroscopy. Special thanks goes to Kevin Pun for the preparation and treatment of titanium alloy disks.

\section{References}

Adell R, Likholm U, Rockler B, Brånemark PI. A 15-year study of osseointegrated implants in the treatment of the edentulous jaw. Int J Oral Surg. 1981; 10:387-416. [PubMed: 6809663]

Adell R, Eriksen B, Lekholm U, Brånemark PI, Jemt T. A long-term follow-up study of osseointegrated implants in the treatment of totally edentulous jaws. Int J Oral Maxillofac Implants. 1990; 5:347-359. [PubMed: 2094653]

Ask M, Lausmaa J, Kasemo B. Preparation and surface spectroscopic characterization of oxide films on Ti6A14V. Appl Surf Sci. 1988; 35:283-301.

Barber TA, Golledge SI, Castner DG, Healy KE. Peptide-modified p(AAmco- EG/AAc) IPN's grafted to bulk titanium modulate osteoblast behavior in vitro. J Biomed Mater Res. 2003; 64:38-47. 
Bonewald LF, Harris SE, Rosser J, Dallas MR, Dallas SL, Camacho NP, Boyan B, Boskey A. von Kossa staining alone is not sufficient to confirm that mineralization in vitro represents bone formation. Calcif Tissue Int. 2003; 725:537-547. [PubMed: 12724828]

Clark PA, Moioli EK, Sumner DR, Mao JJ. Porous implants as drug delivery vehicles to augment host tissue integration. FASEB J. 2008; 22(6):1684-1693. [PubMed: 18198217]

Declercq HA, Verbeeck RMH, de Ridder L, Schacht EH, Cornelissen MJ. Calcification as an indicator of osteoinductive capacity of biomaterials in osteoblastic cell cultures. Biomaterials. 2005; 26:4964-4974. [PubMed: 15769532]

F-86 AS. Annual book of ASTM standards. Vol. 13.01. USA: American Society for Testing and Materials; 1996. Standard practice for surface preparation and marking of metallical surgical implants; p. 6-8.

Franceschi RT, Iyer BS. Relationship between collagen synthesis and expression of the osteoblast phenotype in MC3T3-E1 cells. J Bone Miner Res. 1992; 7:235-246. [PubMed: 1373931]

George EL, Georges-Labouesse EN, Patel-King RS, Rayburn H, Hynes RO. Defects in mesoderm, neural tube and vascular development in mouse embryos lacking fibronectin. Development. 1993; 119:1079-1091. [PubMed: 8306876]

Grossmann Y, Levin L. Success and survival of single dental implants placed in sites of previously failed implants. J Periodontol. 2007; 78:1670-1674. [PubMed: 17760534]

Harbers GM, Healy KE. The effect of ligand type and density on osteoblast adhesion, proliferation, and matrix mineralization. J Biomed Mater Res. 2005; 75:855-869.

Hardt CR, Grondahl K, Lekholm U, Wennstrom JL. Outcome of implant therapy in relation to experienced loss of periodontal bone support: A retrospective 5-year study. Clin Oral Implants Res. 2002; 13:488-494. [PubMed: 12453125]

Hunter GK, Goldberg HA. Nucleation of hydroxyapatite by bone sialoprotein. Proc Natl Acad Sci USA. 1993; 90:8562-8565. [PubMed: 8397409]

Hynes RO. Integrins: Bidirectional, allosteric signaling machines. Cell. 2002; 110:673-687. [PubMed: 12297042]

Imam, MA.; Fraker, AC. Titanium alloys as implant materials. In: Brown, SA.; Lemons, JE., editors. Medical applications of titanium and its alloys. Philadelphia: American Society for Testing and Materials; 1996. p. 3-16.

Johansson P, Strid KG. Assessment of bone quality from cutting resistance during implant surgery. Int J Oral Maxillofac Implants. 1994; 9:279-288.

Joos U, Wiesmann HP, Szuwart T, Meyer U. Mineralization at the interface of implants. Int J Oral Maxillofac Surg. 2006; 35:783-790. [PubMed: 16697141]

Kasemo B. Biocompatibility of titanium implants:surface science aspects. J Prosthetic Dent. 1983; 49:832-837.

Klein MO, Bijelic A, Ziebart T, Koch F, Kämmerer PW, Wieland M, Konerding MA, Al-Nawas B. Submicron scale-structured hydrophilic titanium surfaces promote early osteogenic gene response for cell adhesion and cell differentiation. Clin Implant Dent Relat Res. 2011 DOI:10.1111/j. 1708-8208.00339.x. [Epub ahead of print].

Larsson G, Thomsen P, Aronsson BO, Rodahl M, Lausmaa J, Kasemo B, Ericson LE. Bone response to surface-modified titanium implants: Studies on the early tissue response to machined and electropolished implants with different oxide thicknesses. Biomaterials. 1996; 17:605-616. [PubMed: 8652779]

Lausmaa, J. Mechanical, thermal, chemical and electrochemical surface treatment of titanium. In: Brunette, DM.; Tengvall, P.; Textor, M.; Thomsen, P., editors. Titanium in medicine: Material science, surface science, engineering, biological responses and medical applications. New York: Springer; 2001. p. 232-266.

MacDonald DE, Markovic B, Allen M, Somasundaran P, Boskey AL. Surface analysis of human plasma fibronectin adsorbed to commercially pure titanium materials. J Biomed Materials Res. 1998; 41:120-130.

MacDonald DE, Betts F, Doty SB, Boskey AL. A methodological study for the analysis of apatitecoated dental implants retrieved from humans. Ann Periodontol. 2000; 5(1):175-184. [PubMed: $11885178]$ 
MacDonald DE, Deo N, Markovic B, Stranick M, Somasundaran P. Adsorption and dissolution behavior of human plasma fibronectin on thermally and chemically modified titanium dioxide particles. Biomaterials. 2002; 23:1269-1279. [PubMed: 11791930]

MacDonald DE, Rapuano BE, Deo N, Stranick M, Somasundaran P, Boskey AL. Thermal and chemical modification of titanium-aluminum-vanadium implant materials: Effects on surface properties, glycoprotein adsorption, and MG63 cell attachment. Biomaterials. 2004; 25:31353146. [PubMed: 14980408]

MacDonald DE, Rapuano BE, Schniepp HC. Surface oxide net charge of a titanium alloy: Comparison between effects of treatment with heat or radiofrequency plasma glow discharge. Colloids Surf B Biointerfaces. 2011; 82:173-181. [PubMed: 20880672]

Machtei EE, Mahler D, Oettinger-Barak O, Zuabi O, Horwitz J. Dental implants placed in previously failed sites: Survival rate and factors affecting the outcome. Clin Oral Implants Res. 2008; 19:259264. [PubMed: 18177430]

Meng Y, Qin YX, DiMasi E, Ba X, Rafailovich M, Pernodet N. Biomineralization of a self-assembled extracellular matrix for bone tissue engineering. Tissue Eng A. 2009; 15(2):355-366.

Moioli EK, Mao JJ. Chondrogenesis of mesenchymal stem cells by controlled delivery of transforming growth factor beta3. Conf Proc IEEE Eng Med Biol Soc. 2006; 1:2647-2650. [PubMed: 17946969]

Moioli EK, Hong L, Guardado J, Clark PA, Mao JJ. Sustained release of TGFbeta3 from PLGA microspheres and its effect on early osteogenic differentiation of human mesenchymal stem cells. Tissue Eng. 2006; 12(3):537-546. [PubMed: 16579687]

Morris HF, Winkler S, Ochi S. A 48-month multicenter clinical investigation: Implant design and survival. J Oral Implantol. 2001; 27:180-186. [PubMed: 12500876]

Moursi AM, Damsky CH, Lutt J, Zimmerman D, Doty SB, Aota S, Globus RK. Fibronectin regulates calvarial osteoblast differentiation. J Cell Sci. 1996; 109:1369-1390. [PubMed: 8799825]

Olivares-Navarrete R, Hyzy SL, Hutton DL, Erdman CP, Wieland M, Boyan BD, Schwartz Z. Direct and indirect effects of microstructured titanium substrates on the induction of mesenchymal stem cell differentiation towards the osteoblast lineage. Biomaterials. 2010; 31(10):2728-2735. [PubMed: 20053436]

Rapuano BE, MacDonald DE. Surface oxide net charge of a titanium alloy Modulation of fibronectinactivated attachment and spreading of osteogenic cells. Colloids Surf B Biointerfaces. 2011; 82:95-103. [PubMed: 20884181]

Rapuano BE, Wu C, MacDonald DE. Osteoblast-like cell adhesion to bone sialoprotein peptides. J Orthop Res. 2004; 22:353-361. [PubMed: 15013096]

Rapuano BE, Lee JJ, MacDonald DE. Titanium alloy surface oxide modulates the conformation of adsorbed fibronectin to enhance its binding to a5 $\beta 1$ integrins in osteoblasts. Eur J Oral Sci. 2012a; 120(3):185-194. [PubMed: 22607334]

Rapuano BE, Hackshaw KM, Schniepp HC, MacDonald DE. Surface coating of a titanium alloy with fibronectin augments expression of osteoblast gene markers in the MC3T3 osteoprogenitor cell line. J Oral Maxillofacial Implants. 2012b; 27(5):1081-1090.

Rapuano BE, Hackshaw K, Macdonald DE. Heat or radiofrequency glow discharge pretreatment of a titanium alloy stimulates osteoblast gene expression in the MC3T3 osteoprogenitor cell line. J Periodontal Implant Sci. 2012c; 42(3):95-104. [PubMed: 22803011]

Rezania A, Thomas CH, Branger AB, Waters CM, Healy KE. The detachment strength and morphology of bone cells contacting materials modified with a peptide sequence found within bone sialoprotein. J Biomed Mater Res. 1997; 37:9-19. [PubMed: 9335344]

Sauberlich S, Klee D, Richter EJ, Hocker H, Spiekermann H. Cell culture tests for assessing the tolerance of soft tissue to variously modified titanium surfaces. Clin Oral Implants Res. 1999; 10:379-393. [PubMed: 10551063]

Sieving A, Wu B, Mayton L, Nasser S, Wooley PH. Morphological characteristics of total joint arthroplasty-derived ultra-high molecular weight polyethylene wear (UHMWPE) debris that provoke inflammation in a murine model of inflammation. J Biomed Mater Res. 2003; 64A:457464. 
Sousa SR, Lamghari M, Sampaio P, Moradas-Ferreira P, Barbosa MA. Osteoblast adhesion and morphology on $\mathrm{TiO} 2$ depends on the competitive preadsorption of albumin and fibronectin. $\mathrm{J}$ Biomed Mater Res A. 2008; 84:281-290. [PubMed: 17607748]

Sudo H, Kodama HA, Amagai Y, Yamamoto S, Kasai S. In vitro differentiation and calcification in a new clonal osteogenic cell line derived from newborn mouse calvaria. J Cell Biol. 1983; 96:191198. [PubMed: 6826647]

Tengvall P, Lundström I. Physico-chemical considerations of titanium as a biomaterial. Clin Mater. 1992; 9:115-134. [PubMed: 10171197]

ter Brugge PJ, Wolke JG, Jansen JA. Effect of calcium phosphate coating crystallinity and implant surface roughness on differentiation of rat bone marrow cells. J Biomed Mater Res. 2002; 60(1): 70-78. [PubMed: 11835161]

Wang D, Christensen R, Chawla K, Xiao G, Krebsbach PH, Franceschi RT. Isolation and characterization of MC3T3-E1 preosteoblast sub-clones with distinct in vitro differentiation/ mineralization potential. J Bone Miner Res. 1999; 14:893-903. [PubMed: 10352097]

Webster TJ. Nanophase ceramics as improved bone tissue engineering materials. Am Ceram Soc Bull. $2003 ; 82: 1-8$.

Willis JB. Determination of calcium in blood serum by atomic absorption spectroscopy. Nature. 1960; 186:249-250. [PubMed: 13844983]

Zhao G, Raines AL, Wieland M, Schwartz Z, Boyan BD. Requirement for both micron and submicron scale structure for synergistic responses of osteoblasts to substrate surface energy and topography. Biomaterials. 2007; 28 (18):2821-2829. [PubMed: 17368532] 


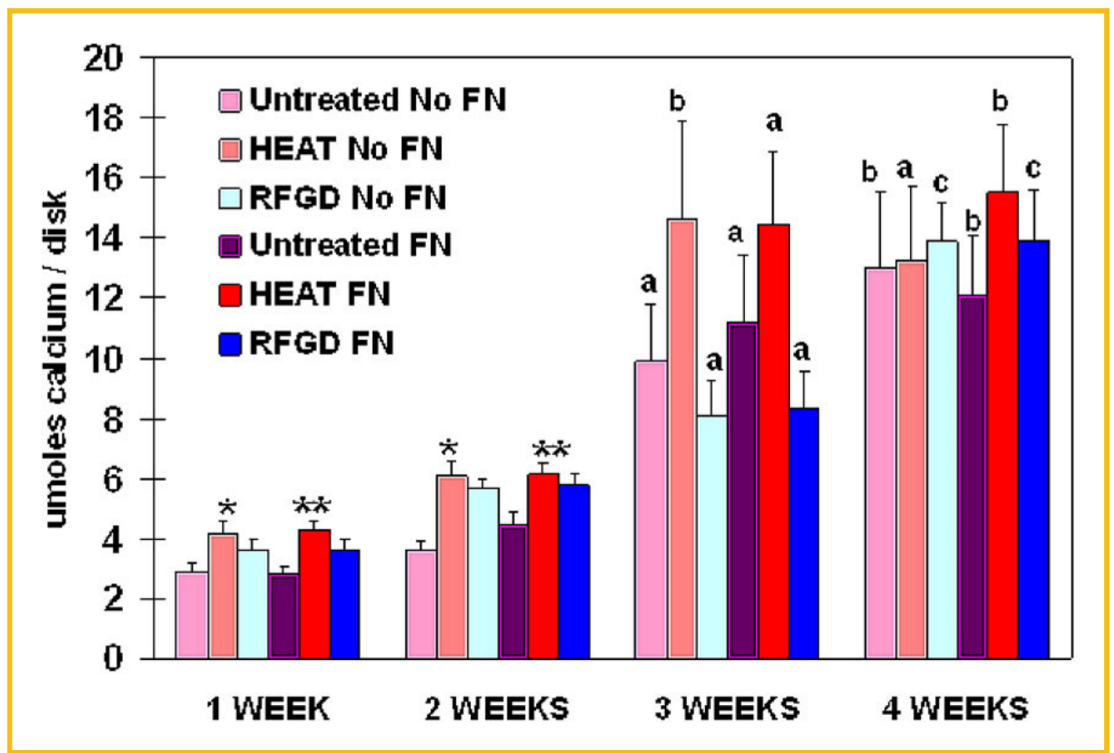

Fig. 1.

Effects of heat and RFGD pretreatments of Ti6Al4V disks on total soluble calcium levels in MC3T3 osteoprogenitor cell cultures. Both untreated and pretreated disks were either uncoated (No FN) or precoated $(\mathrm{FN})$ with $1 \mathrm{nM}$ fibronectin overnight and plated with MC3T3 cells. Cultures were incubated for 1-4 weeks in cell culture media containing $50 \mu \mathrm{g} /$ $\mathrm{ml}$ ascorbic acid and $3 \mathrm{mM} \beta$ glycerophosphate. Total soluble calcium was extracted from the surface of disks at the indicated incubation time points and measured by flame atomic absorption spectrophotometry. Total soluble calcium levels are presented as umoles/disk. Data represent means $\pm \mathrm{SE}$ for a minimum of four independent cultures at each time point. *,**Significantly greater $(P<0.05)$ than untreated No FN disks or untreated FN disks, respectively, measured at the same time point based on analysis of variance. ${ }^{\mathrm{a}-\mathrm{c}}$ Significantly greater compared to the same experimental condition measured at 1 week ( $P$ $<0.05$ or less); 1 and 2 weeks ( $P<0.05$ or less); or 1,2 , and 3 weeks $(P<0.01$ or less), respectively, based on analysis of variance. FN, fibronectin; HEAT, heat pretreatment; RFGD, radiofrequency plasma glow discharge pretreatment. 


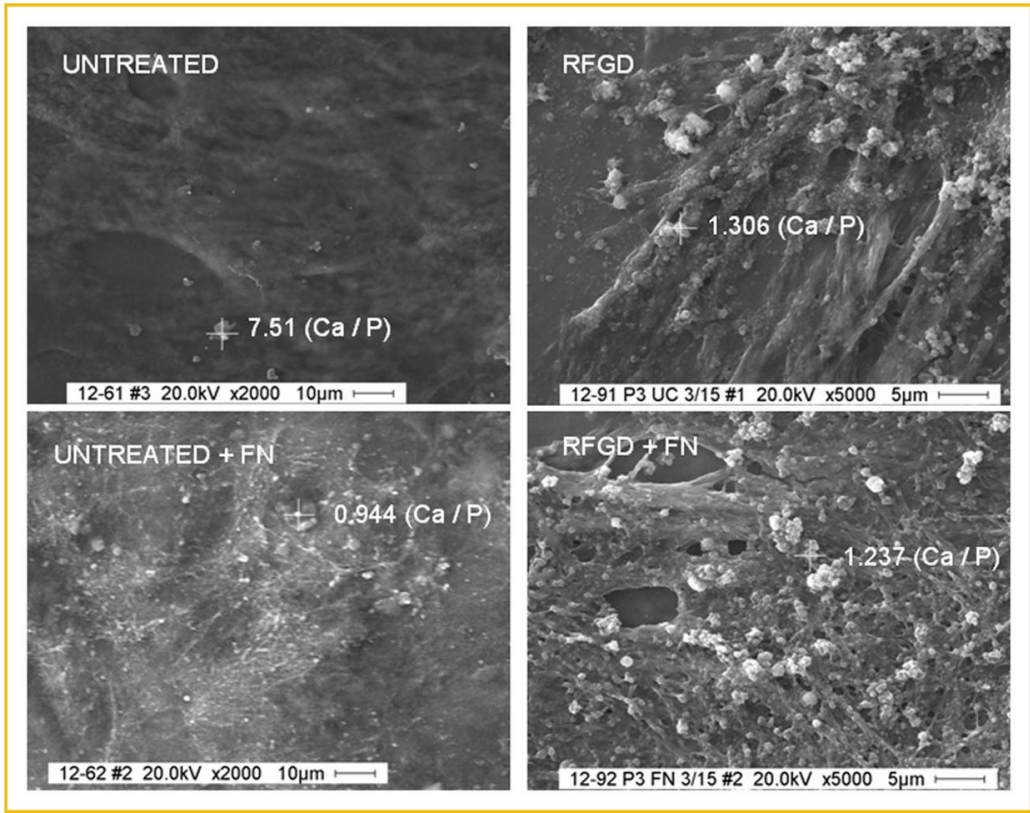

Fig. 2.

Scanning electron micrographs and EDAX analysis of MC3T3 osteoprogenitor cell cultures grown on untreated or RFGD-pretreated Ti6Al4V disks that were uncoated or fibronectincoated (FN). Cells were plated on disks, incubated with cell culture media containing $50 \mu \mathrm{g} /$ $\mathrm{ml}$ ascorbic acid and 3mM $\beta$-glycerophosphate for 3 weeks, fixed in $4 \%$ paraformaldehyde, images were captured by SEM and selected particles (marked by crosshairs) that appeared brighter than background were analyzed by EDAX. The calcium: phosphorus mass ratio determined by EDAX analysis of the atomic composition of each selected particle is shown next to the crosshairs overlying that particle. Calcium: phosphorus mass ratios were determined by dividing the AUC (area under the curve) for the calcium elemental scan by the AUC for the phosphorus elemental scan. Images of UNTREATED disks are shown at 2,000× magnification; those of RFGD-PRETREATED DISKS are shown at 5,000× magnification. FN, fibronectin; RFGD, radiofrequency plasma glow discharge pretreatment. 


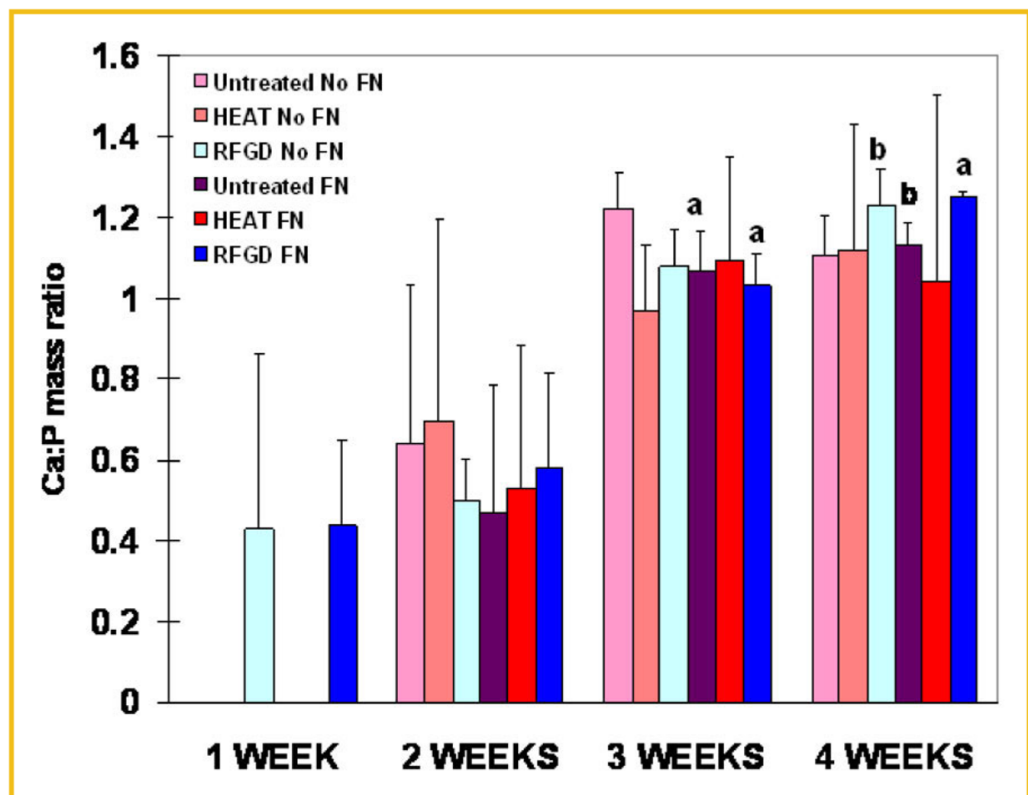

Fig. 3.

EDAX analysis of mineral formed in MC3T3 osteoprogenitor cell cultures incubated for 1-4 weeks on untreated or pretreated Ti6Al4V disks that were uncoated or fibronectin-coated (FN). Cells were plated on disks, incubated with cell culture media containing $50 \mu \mathrm{g} / \mathrm{ml}$ ascorbic acid and 3mM $\beta$ glycerophosphate for 1-4 weeks, fixed in $4 \%$ paraformaldehyde and images were captured by SEM. EDAX spectra were obtained for selected particles for each of the three experimental groups. Data represent means \pm SE for a minimum of three independent cultures at each time point. No particles of any size containing calcium or phosphorus were detected on untreated or heat pretreated disks for the 1 week time point. ${ }^{\mathrm{a}, \mathrm{b}}$ Significantly greater compared to the same experimental condition measured at 1 week ( $P$ $<0.05$ or less) or 1 and 2 weeks $(P<0.05$ or less), respectively, based on analysis of variance. FN, fibronectin; HEAT, heat pretreatment; RFGD, radiofrequency plasma glow discharge pretreatment. 


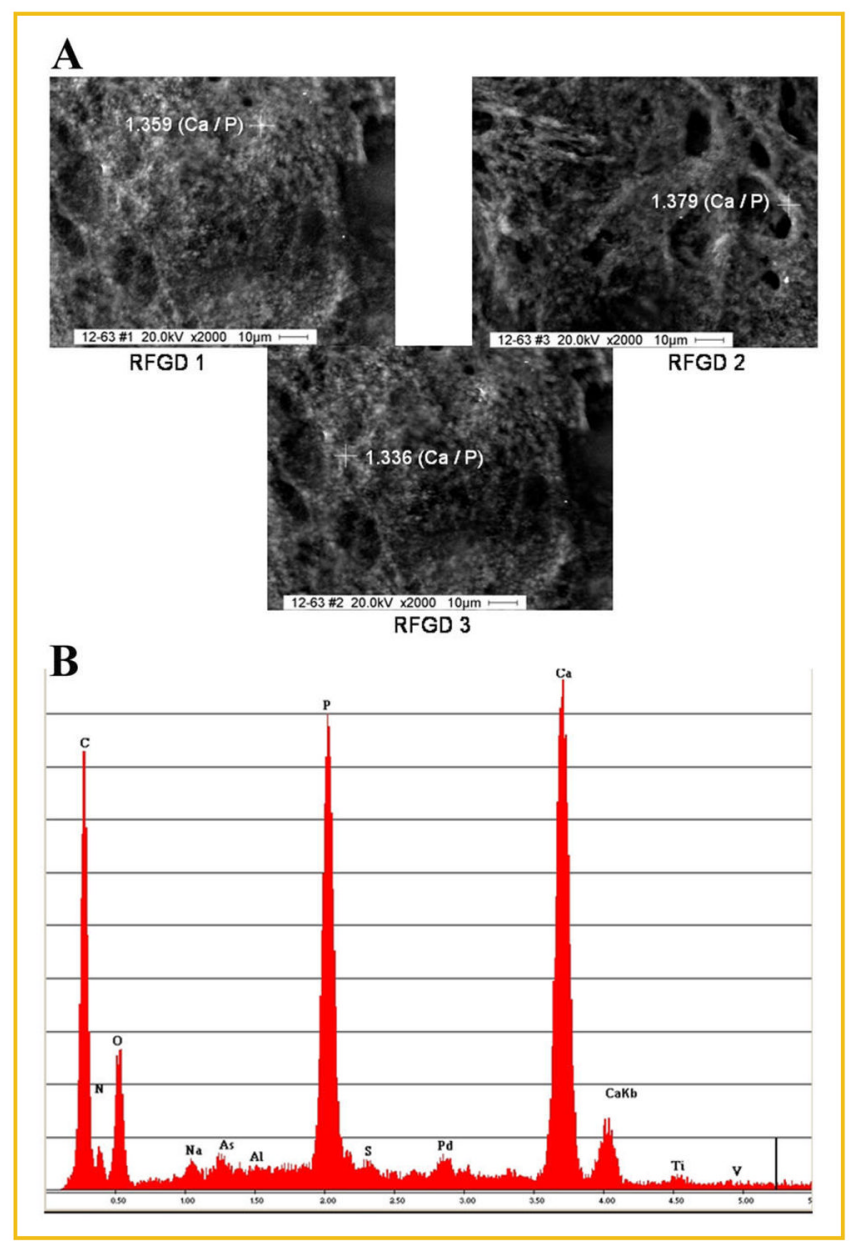

Fig. 4.

SEM and EDAX analysis of mineral formed in MC3T3 osteoprogenitor cell cultures grown on an RFGD-pretreated uncoated Ti6Al4V disk. Cells were cultured on an RFGD-pretreated disk (without fibronectin coating) with cell culture media containing $50 \mu \mathrm{g} / \mathrm{ml}$ ascorbic acid and $3 \mathrm{mM} \beta$-glycerophosphate for 4 weeks, fixed in $4 \%$ paraformaldehyde, images were captured by SEM and selected particles were analyzed by EDAX. A: Particles analyzed by EDAX in three regions of the same disk (RFGD1, RFGD2, and RFGD3) are marked by crosshairs; the Ca:P mass ratio determined by EDAX analysis of the atomic composition of each particle is shown next to the crosshairs overlying that particle. B: The EDAX spectra obtained for the particle analyzed in RFGD3 is shown. Images are shown at 2,000x magnification. RFGD, radiofrequency plasma glow discharge pretreatment. 


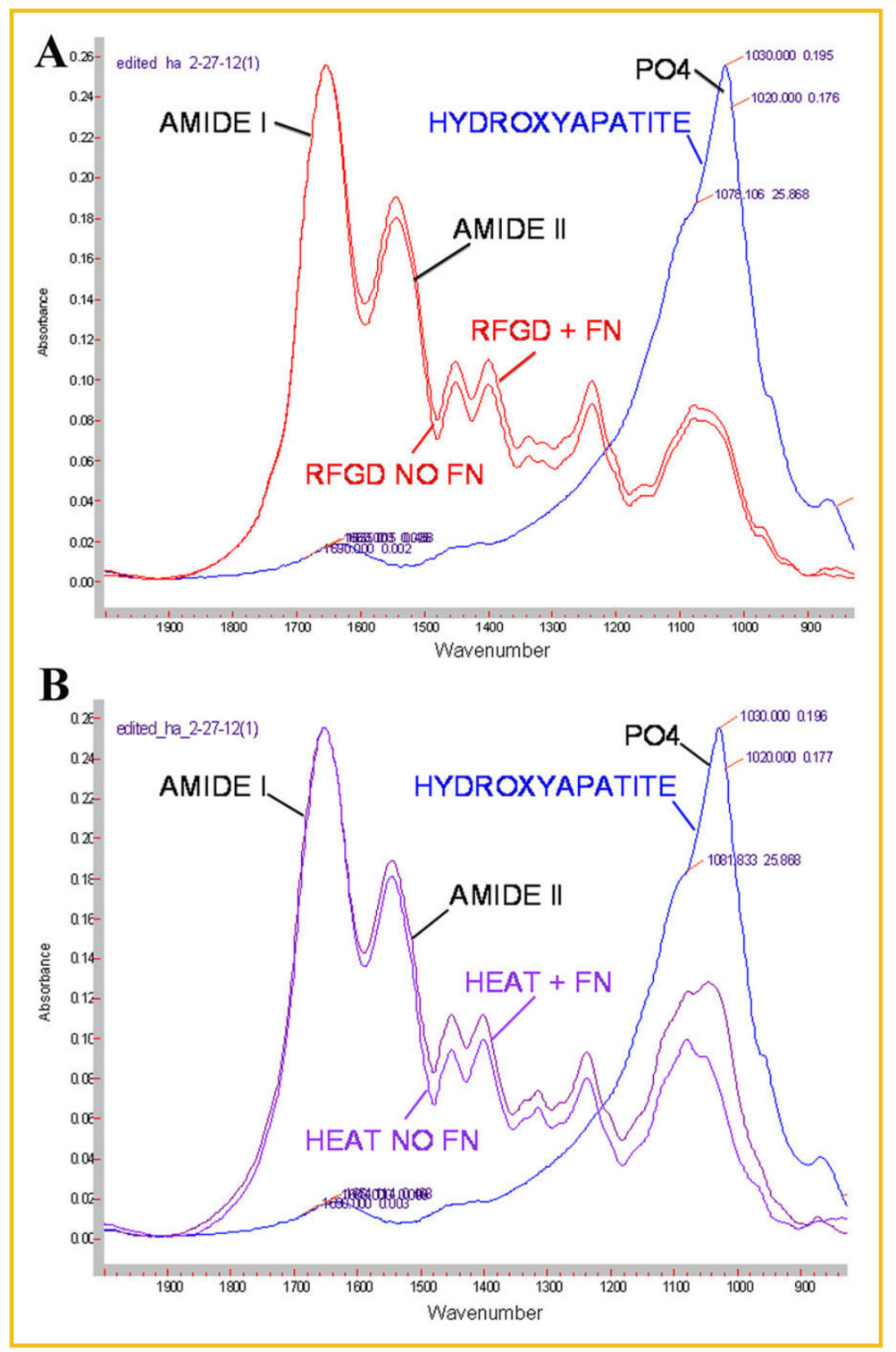

Fig. 5.

FTIR spectroscopic analysis of mineral formed in MC3T3 osteoprogenitor cell cultures on RFGD-pretreated or HEAT-pretreated fibronectin-coated or uncoated Ti6Al4V disks. Cells were plated on disks and incubated with cell culture media containing $50 \mu \mathrm{g} / \mathrm{ml}$ ascorbic acid and 3mM $\beta$-glycerophosphate for 4 weeks. FTIR spectroscopic analyses were performed on pellets prepared from $\mathrm{KBr}$ combined with air-dried samples of the material that covered the disks. Combined spectra obtained from synthetic hydroxyapatite (HYDROXYAPATITE) and (A) RFGD-pretreated fibronectin-coated (RFGD+FN) and uncoated (RFGD NO FN) disks; or (B) HEAT-pretreated fibronectin-coated (HEAT+FN) and uncoated (HEAT NO FN) disks, are shown. PO4 — characteristic apatite phosphate peak (900-1,200 $\mathrm{cm}^{-1}$ ). AMIDE I and AMIDE II- characteristic extracellular matrix protein amide peaks. FN, fibronectin; HEAT, heat pretreatment; RFGD, radiofrequency plasma glow discharge pretreatment. 


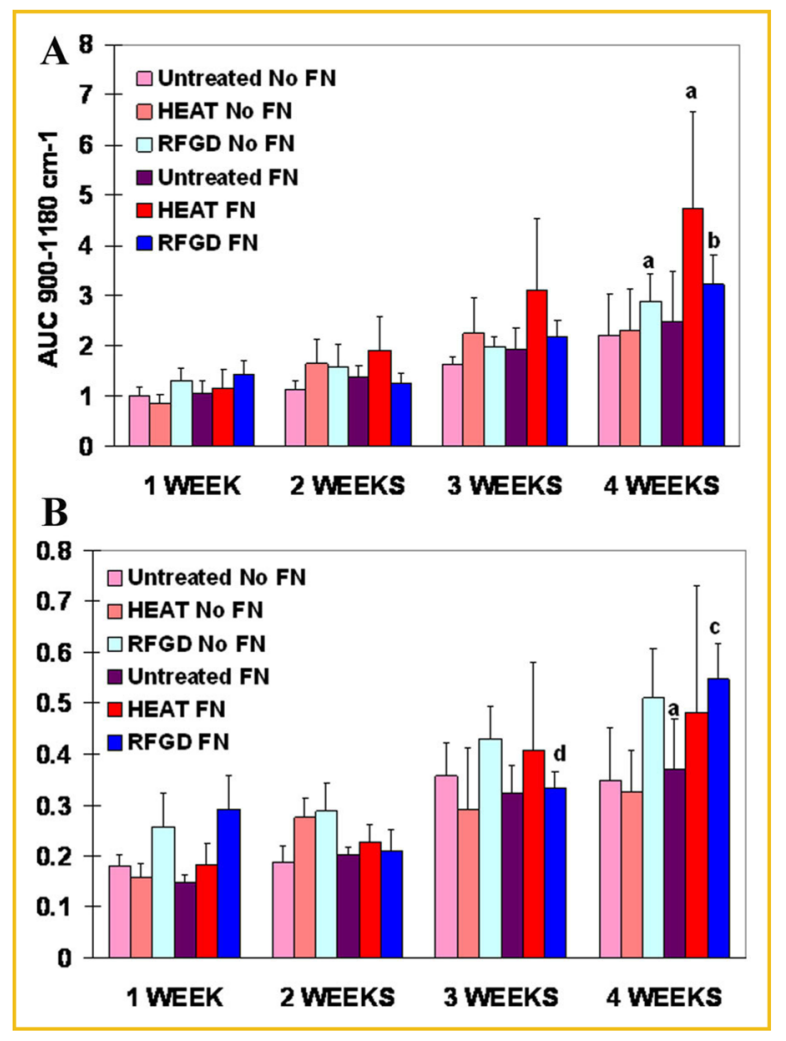

Fig. 6.

FTIR spectroscopic measurements of the effects of heat and RFGD pretreatments of Ti6Al4V disks on calcium-phosphate mineral levels and the mineral:matrix ratio in MC3T3 osteoprogenitor cell cultures. Cells were incubated with cell culture media containing ascorbic acid and $\beta$ glycerophosphate for 1-4 weeks. FTIR spectroscopic analyses were performed on pellets prepared from $\mathrm{KBr}$ combined with air-dried samples of the material that covered the disks. Relative levels of calcium-phosphate mineral (A) were measured as the area under the apatite phosphate peak $\left(900-1,180 \mathrm{~cm}^{-1}\right)$. Data were normalized to the area under the apatite phosphate peak $\left(900-1,200 \mathrm{~cm}^{-1}\right)$ for untreated and uncoated disks at 1 week. The mineral to matrix ratio (B) was determined as the area under the phosphate peak $\left(900-1,180 \mathrm{~cm}^{-1}\right)$ divided by the area under the amide I peak $\left(1,585-1,720 \mathrm{~cm}^{-1}\right)$. Both the levels of calcium-phosphate mineral and the mineral:matrix ratio were corrected for control (no supplementation with ascorbic acid or $\beta$ glycerophosphate) values. Data represent means \pm SE for 3-5 independent cultures at each time point. ${ }^{a-d}$ Significantly greater compared to the same experimental condition measured at 1 week $(P<0.05) ; 1$ and 2 weeks $(P<0.05)$; 1,2 , and 3 weeks $(P<0.001)$; or 2 weeks $(P<0.05)$, respectively, based on analysis of variance. FN, fibronectin; HEAT, heat pretreatment; RFGD, radiofrequency plasma glow discharge pretreatment. 